\title{
48. İki Fransızca öğretim kitabının dilbilgisi öğretimi açısından karşılaştırmalı çözümlemesi: Défi ve L'atelier
}

\section{Özge ÖZBEK ${ }^{1}$}

\begin{abstract}
APA: Özbek, Ö. (2021). İki Fransızca öğretim kitabının dilbilgisi öğretimi açısından karşılaştırmalı çözümlemesi: Défi ve L'atelier. RumeliDE Dil ve Edebiyat Araştırmaları Dergisi, (23), 753-767. DOI: $10.29000 /$ rumelide.949693.
\end{abstract}

\section{$\ddot{O} \mathbf{z}$}

Geçmişten günümüze yabancı dil eğitim-öğretiminde dilbilgisinin yeri büyük ölçüde değişmiştir. Yeni yöntemlerle birlikte önceden pasif durumda olan öğrenci, günümüzde düşünmeye ve sorgulamaya teşvik edilerek aktif duruma getirilmiştir. Dilin yadsınamaz bir kısmını oluşturan dilbilgisinin yabancı dil eğitim-öğretimi içerisindeki yerinin yıllar içinde oldukça değiştiği söylenebilir. Eskiden yabancı dil öğretiminde amaç olan ve derslerde açıça öğretilen dilbilgisi günümüzde derslere ve ünitelere örtük olarak dahil edilmekte, öğrenciye çeşitli örnekler verilip genelleme ve dilbilgisi kuralını oluşturma işi öğrenciden beklenmektedir. Bu şekilde yabancı dil öğretiminde önceden pasif durumda olan öğrenci, günümüzde düşünmeye ve sorgulamaya teşvik edilerek aktif duruma getirilmiştir. Bu çalışmada öncelikle Fransızca dilbilgisinin, çeşitli yabancı dil öğretim yöntem ve yaklaşımlarındaki öğretim şekli hakkında bilgi verilmiştir. Ardından başka bir başlık altında dilbilgisi türlerinin bazı yazarlara göre yapılmış sınıflandırmaları irdelenmiştir. Ayrıca tümce dilbilgisi ve zaman içinde yapısalcı dilbilimin etkisiyle ortaya çımış olan metin dilbilgisi gibi farklı dilbilgisi türlerine de yer verilmiştir. Çalışmayı somutlaştırmak amacıyla Maison des langues ve Didier yayınevleri tarafından yayımlanmış Défi 3 B1 ve L'atelier B1 Fransızca öğretim kitapları dilbilgisi öğretimi açısından hem Jean-Pierre Cuq’ün geliştirdiği dilbilgisi çözümleme ölçeğiyle hem de Diller Iç̧in Avrupa Ortak Başvuru Metni (OBM) B1 düzeyi dilbilgisi konularına uygun olarak incelenmiş ve karşılaştırılmıştır. Sonuç olarak, bazı dilbilgisi konularının kitaplara dahil edilmesi konusunda birtakım öneriler getirilmiştir.

Anahtar kelimeler: Dilbilgisi öğrenimi/öğretimi, yabancı dil olarak Fransızca, Fransızca öğretim kitapları, B1 düzeyi

\section{A comparative analysis of two French course books in terms of grammar teaching: Défi and L'atelier}

\begin{abstract}
The place of grammar in foreign language teaching has changed greatly over the time. With new methods, students who are previously passive recipients, have been turned into active persons by encouraging them to consider and to interrogate. It can be said that the place of grammar, which constitutes an important part of the language, has changed considerably over the years in foreign language teaching. It was the main goal of the language learning and it was explicitly taught before. But nowadays it is implicitly integrated to the lessons. Various examples are given to the learners and the work of creating the grammar rule is expected from them. In this way, the learner, who was in a passive position in foreign language teaching, has now been encouraged to think and question.
\end{abstract}

Ars. Gör., Gazi Üniversitesi, Gazi Eğitim Fakültesi, Yabancı Diller Eğitimi Bölümü, Fransız Dili Eğitimi ABD (Ankara, Türkiye), ozgekaracadal@gazi.edu.tr, ORCID ID: oooo-0oo1-6386-2191 [Araştırma makalesi, Makale kayıt tarihi: 24.03.2021-kabul tarihi: 20.06.2021; DOI: 10.29000/rumelide.949693]

Adres $\mid$ Address

RumeliDE Dil ve Edebiyat Araşttrmaları Dergisi $\quad$ RumeliDE Journal of Language and Literature Studies Osmanağa Mahallesi, Mürver Çiçeği Sokak, No:14/8 $\quad$ Osmanağa Mahallesi, Mürver Çiçeği Sokak, No:14/8

Kadıköy - İSTANBUL / TÜRKIYE 34714 Kadıköy - ISTANBUL / TURKEY 34714 e-posta: editor@rumelide.com

e-mail: editor@rumelide.com,

tel: +90 505 7958124, +90 216773 o 616 phone: +90 505 7958124, +90 2167730616 
In this study, the way of teaching French grammar is summarized in various foreign language teaching methods and approaches. Then, under another title, different classifications of grammar types were observed according to several authors. Besides, grammar types such as text grammar, which is developed under the influence of structural linguistics, and sentence grammar are included in the study. With the intention of concretising the study, two French course books, published by publishing houses Maison des langues and Didier, Défi 3 B1 and L'atelier B1, were examined and compared in terms of grammar teaching in two ways: according to the grammar scale of Jean-Pierre Cuq and grammar subjects in level B1 of the Common European Framework of Reference for languages (CEFR). As a result, suggestions were offered regarding the integration of some grammar topics in these course books.

Keywords: Grammar learning/teaching, French as a foreign language, French course books, level B1 in French

\section{Giriş}

Dilin önemli bir kısmını oluşturan dilbilgisi ve öğretimi çalışma konusu olarak belirlenmiştir. Dilbilgisi sözcügü Neveu’ye göre "dilin sesbilimsel, biçimbilimsel ve sözdizimsel kurallarını anlamayı sağlayan tüm yapısal özelliklerini" kapsar (Neveu, 2015, s. 172-173). Bir mobil uygulama olan Le Robert Dixel Mobile sözlüğünde (t.y.) ise dilbilgisi terimi "bir dili doğru konuşmak ve yazmak için takip edilmesi gereken kurallar bütünü" olarak açıklanmaktadır. Bu bağlamda, çalışmada ilk olarak geçmişten günümüze yabancı dil öğretiminde dilbilgisinin yerinden söz edilecek, daha sonra dilbilgisi türleri açıklanacak ve yabancı dil olarak Fransızca öğretim kitaplarında dilbilgisinin yeri sorgulanacaktır.

\section{Amaç ve yöntem}

Çalışmadaki başlıca amaç, dilbilgisinin incelenecek olan Fransızca öğretim kitaplarında nasıl ele alındığını ortaya koymaktır. Çalışmanın sorunsalını aşağıdaki sorular oluşturmaktadır:

- Fransızcanın yabancı dil olarak öğretiminde kullanılan son yıllarda yayınlanmış olan öğretim kitaplarında dilbilgisi öğretim şekli/yöntemi nasıldır? Bu durum yayınevlerine göre değişmekte midir? Fransızcanın yabancı dil olarak öğretildiği aynı düzeydeki öğretim kitaplarında (seçilen iki farklı B1 kitabı) dilbilgisi konuları paralellik göstermekte midir?

- Kitaplardaki dilbilgisi öğretim şekli Avrupa Ortak Başvuru Metni’nde (OBM) benimsenen yaklaşıma uygun mudur? Bu kitaplarda öğretilen dilbilgisi konuları OBM’ye göre B1 düzeyinde öğretilmesi gereken konularla tutarlı mıdır?

- Cuq’ün dilbilgisi çözümleme ölçeğiyle söz konusu Fransızca öğretim kitapları incelendiğinde ne gibi sonuçlar elde edilebilir?

Çalışmada benimsenen yöntemler nitel veri analizi yöntemlerinden betimsel, karşılaştırmalı ve belge incelemesi yöntemleridir. Betimsel analizde veriler belirli bir tematik yaklaşımla incelenir, sınıflandırılır ve yorumlanır (Akbulut, 2012, s. 186). Belge incelemesi ise aşağıdaki şekilde tanımlanmaktadır:

Belge incelemesi, araştırılması istenen konu hakkında bilgi içeren yazılı, görsel ya da işitsel materyallerin çözümlenmesidir. Bu yaklaşım, gözlem ve görüşmenin olanaklı olmadığı durumlarda tek başına veri toplama aracı olarak kullanılabileceği gibi gözlem ve görüşme verileri desteklemek ve araştırmanın geçerliğini artırmak amacıyla da ek bilgi kaynağı olarak da kullanılabilir (Balaban Salı, 2012, s. 151).

\begin{tabular}{r|l} 
Adres & Address \\
RumeliDE Dil ve Edebiyat Araşttrmaları Dergisi & RumeliDE Journal of Language and Literature Studies \\
Osmanağa Mahallesi, Mürver Çiçeği Sokak, No:14/8 & Osmanağa Mahallesi, Mürver Çiçeği Sokak, No:14/8 \\
Kadıköy - İSTANBUL / TÜRKIYY 34714 & Kadıköy - ISTANBUL / TURKEY 34714 \\
e-posta: editor@rumelide.com & e-mail: editor@rumelide.com, \\
tel: +90 505 7958124, +90 2167730616 & phone: +90 505 7958124, +90 216773 o 616
\end{tabular}


Bu kapsamda Défi B1 ve L'Atelier B1 kitaplarındaki dilbilgisiyle ilişkili olan metin, fotoğraf, resim ve ses kaydı görsel-işitsel belge kabul edilip araştırmaya dahil edilmiş; her iki kitapta yer verilen dilbilgisi konuları karşılaştırılarak bir sonuca varılmıştır.

Günümüze kadar hem Türkiye'de hem de başka ülkelerde Fransızcanın yabancı dil olarak öğretiminde dilbilgisinin ele alındığı veya Fransızcanın yabancı dil olarak öğretildiği öğretim kitaplarının genel anlamda incelendiği birçok çalışma uzmanlar tarafından gerçekleştirilmiştir (bkz. Bérard, 2019; Mawushi ve Ganyo, 2015; Özçelik, 2012). Ancak bu çalışma iki bakımdan öncekilerden ayrılmaktadır: Birincisi ele alınan kitapların, Fransa Milli Eğitim Bakanlığı tarafından kurulan Uluslararası Pedagojik Eğitim Merkezi'nden (bkz. CIEP, Centre International d'Études Pédagogiques) ve OBM'den edinilen Fransızcanın yabancı dil olarak öğretiminde B1 düzeyinde kazanılması gereken dilbilgisel yetilerle paralellik gösterip göstermediğinin incelenmesi; ikincisi ise bu kitapların Cuq’ün dilbilgisel çözümleme ölçeğine başvurularak incelenmesi ve karşılaştırılmasıdır (1996, s. 111).

\section{Yabancı dil öğretiminde dilbilgisi}

18. ve 19. yüzyıllarda yabancı dil öğretiminde ortaya çıkan Geleneksel Yöntem, ardından 190o'lü yıllarda Doğrudan yöntem ve onu takip eden İşitsel-Sözel Yöntem'de dilbilgisi öğretimi tümevarım yoluyla gerçekleştirilmiştir (Germain, 1993, s. 101-148, Puren, 1988, s. 25-26, 52, 59). "Önce kural verilir, sonra verilen kuralı örnekleyecek nitelikte olan cümlelerle özel durumlara uygulama" gerçekleştirilir (Germain, 1993, s. 101). 1950'li ylllarda ortaya çlkan Görsel-İşitsel Yöntem’i diğerlerinden ayıran özellik ise, dilbilgisi ve sözcük öğretiminde bağlam ve duruma dikkat edilmesidir. Burada G. Gougenheim günlük hayatta en ssk kullanılan sözcükleri bir araya getirerek Temel Fransızca (Français Fondamental ya da $F F$ ) isimli bir liste oluşturmuş ve listenin başında da bazı fiillerin ve diğer dilbilgisi ögelerinin olduğunu belirtmiştir. Aslında temel dilbilgisini gösteren bu liste, bazı zamanların (le passé récent ve le futur proche) diğerlerine göre (le passé simple ve le futur antérieur) daha fazla kullanıldığını ve düzensiz fiillerin düzenlilere göre daha fazla kullanıldığını göstermiştir (s. 158). Bu yöntemdeki saptamalar en fazla kullanılan sözcüklerin dilbilgisi alanında olduğunu göstermiş ve biraz da olsa dilbilgisine dikkat çekmiştir. Söz konusu yöntemde dilbilgisi diyaloglar içinde öğretildiği için tümevarım yoluna başvurulduğu ve örtük bir şekilde öğrenciye sunulduğu söylenebilir.

İletişimsel Yaklaşım’ı önceki yöntemlerden ayıran özelliklerden biri, Avrupa Konseyi'nin görevlendirdiği bir grup uzman tarafından oluşturulan dokümanlarla ortaya çlkmasıdır (1975). İletişimsel yaklaşımla gündeme gelen ve önem verilen nokta iletişim yetisidir (la compétence de communication) ve bu yeti altında 3 alt başlık gösterilir: "dilbilgisi yetisi, sosyo-dilsel yeti ve stratejik yeti" (Canale ve Swain aktaran Bérard, 1991, s. 19). İletişimsel Yaklaşımda öğrenen daha aktif bir konuma getirilir ve dilin işleyişi üzerine düşünmeye yönlendirilir (Bérard, 1991, s. 46-47). Burada da dilbilgisi örtük bir şekilde, tümevarım yöntemiyle, gerçek (otantik) veya gerçeğe yakın materyallerle belli bir bağlam içinde öğrenciye sunulur. Hazırlanan materyaller günlük hayattan alınan metinler veya benzerlerini içerdiğinden, yararlanılan dilbilgisi yapılarının da günlük hayatta en sık kullanılan yapılar olması beklenmektedir. Böylelikle öğrenen kişi günlük dilde kullanılan dilbilgisi kurallarını da duymuş olacak ve ilk planda en çok kullanılan yapılarla karşılaştığı için onların işleyişi üzerine düşünmeye başlayacaktır.

Avrupa Konseyi tarafından hazırlanan Diller İçin Avrupa Ortak Başvuru Metni (OBM), dillerin öğrenimi ve öğretimi, sınavların, kitapların ve programların hazırlanması için geliştirilen ortak bir

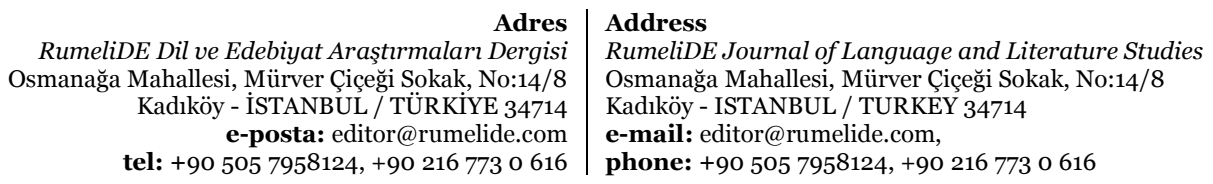


çerçevedir. Ayrıca bu metin 6 farklı dil düzeyinde (A1, A2, B1, B2, C1, C2) öğrenciden beklenen yetileri de belirtmektedir. Bu metinle ortaya çıkan, Avrupa Konseyi’nin önerdiği Eylem Odakl Yaklaşım son yıllarda yayımlanan çoğu yabancı dil öğretim kitabında benimsenen yaklaşım olarak gösterilebilir (MEB, 2009, s. 6). Iletişimsel yaklaşımda "iletişim durumu" na verilen önemin yerini Eylem Odaklı Yaklaşımda ünite sonunda öğrenene verilen son görev (la tâche finale) alır (Puren, 2016, s. 1). Kuduz (2019) Yüksek Lisans tez çalışmasında görev (la tâche) sözcüğünün uzmanlar tarafından birçok farklı şekilde tanımlandığının altını çizer ve bu sözcüğü alıştırma (l'exercice) ve etkinlik (l'activité) sözcüklerinden ayırmanın zorluğundan söz eder. Yazara göre Fransızca olarak hazırlanmış OBM'de de görev ve etkinlik terimlerini netleştirecek, birbirinden ayıracak bir bilgi bulunmamaktadır (2019, s. 27-30). Ülkemizde Fransızcanın yabancı dil olarak öğretimi (FLE) alanında eylem odaklı yaklaşım üzerine gerçekleştirilen çalışmalarda genellikle söz konusu görevleri yerine getirmenin zorluğundan bahsedilir (Aydoğu, Ercanlar ve Aydınalp, 2017, s. 6; Kuduz, 2019, s. 6). Çalışmasında iletişimsel ve eylem odaklı yaklaşımları karşılaştıran Saydı'ya göre, 21.yüzyıldaki yabancı dil öğretiminde öğrenen kişinin iletişimsel becerilerini geliştirme amacı ön plandadır; ancak bu dil öğretimi bazı düzeylerde dilbilgisi yetisini geliştirmekte yetersiz kalmaktadır (Saydı, 2015, s. 16).

\section{Dilbilgisi Türleri}

Dilbilgisi terimi konusunda birçok araştırmacı farklı açıklamalarda bulunmuş ve dilbilgisini türlere ayırırken de farklı şekilde sınıflandırmışlardır. Ancak çalışmamızda Fransızca öğretim kitapları inceleneceğinden bu konuda da Fransız literatürü dikkate alınmıştır. Dolayısıyla bu başlıkta, dilbilgisi türlerini inceleyen belli başlı Fransız yazarlar ve yaptıkları sınıflandırmaların önemi vurgulanacaktır. Söz konusu sınıflandırmaların bir sonraki başlıkta gerçekleştirilecek olan çözümlemeye yardımcı olacağı düşünülmektedir.

Riegel, Pellat ve Rioul'a (2004) göre dilbilgisi terimi için teknik anlamda 3 farklı anlayış gösterilebilir: Kendiliğinden Var Olan Dilbilgisi (la grammaire immanente), İçselleştirilmiş Dilbilgisi (la grammaire intériorisée) ve Betimsel veya Kuramsal Dilbilgisi (une grammaire-description ou grammairethéorie). Öncelikle, Kendiliğinden Var Olan Dilbilgisi dilin sistemini oluşturan, dile özgü ve önceden belli olan niteliklerdir. İçselleştirilmiş Dilbilgisi ise, konuşan kişinin edindiği, herhangi bir cümlenin veya sözcenin dilbilgisel olarak doğru veya yanlış olduğunu hissetmesini sağlayan ama aslında bilinçli olarak öğrenmediği bir dilbilgisidir. Betimsel Dilbilgisi de ayrıntılı çözümlemeler yaparak dilin kuramsal özelliklerini betimleyen dilbilgisidir. Yazarlar ayrıca incelenen konu bazında bakıldığında dört farklı dilbilgisi türü veya dalı bulunduğunu belirtmektedirler: Eşzamanh Dilbilgisi (La grammaire synchronique ou descriptive), Artzamanl Dilbilgisi (La grammaire diachronique ou historique), Karşılaştırmalı Dilbilgisi (La grammaire comparée) ve Genel Dilbilgisi (La grammaire générale) (a.g.e., s. 13). Riegel, Pellat ve Rioul sözü edilen dilbilgisi türleri dışında, bazı kuramsal akımları çağrıştıran terimlerin de dilbilgisini niteleyici konumda olduklarını ve dilbilgisiyle bir arada kullanıldıklarını öne sürer: Dă̆ılımsal (distributionnelle), işlevsel (fonctionnelle), yapısalcı (structurale), dönüşümsel (transformationnelle) (a.g.e., s. 14). Yazarlar aynı zamanda Betimsel Dilbilgisi (La grammaire descriptive) ve Kuralcr Dilbilgisi (La grammaire prescriptive ou normative) türlerine de dikkat çekerler: Birinci türde betimsel bir bakış açısıyla konuşan kişinin söyleminde başvurduğu yapılar incelenir. İkincisinde ise dilin doğru ve yerinde kullanımına önem verilir; hem kuralların doğru kullanımı hem de genel olarak yapılan yanlışlar açıklanır. (a.g.e., s. 1416).

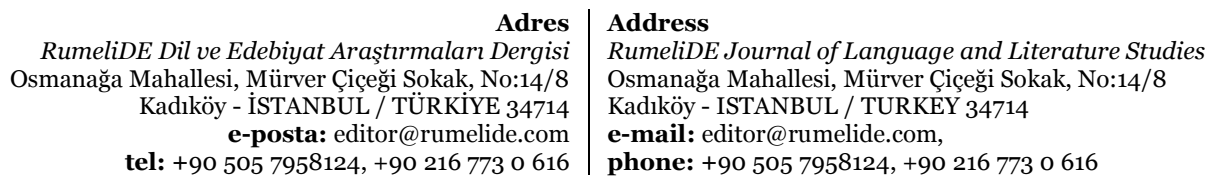


Germain ve Séguin ise Dirven'in (1990, s. 1) tablosundan yola çıkarak yeni bir sınıflandırma önerirler ve aşă̆ıda gösterildiği üzere Dilbilgisi terimini iki ana türe ayırıp onları da alt türlere bölüp toplamda dört dilbilgisi türüne ulaşırlar:

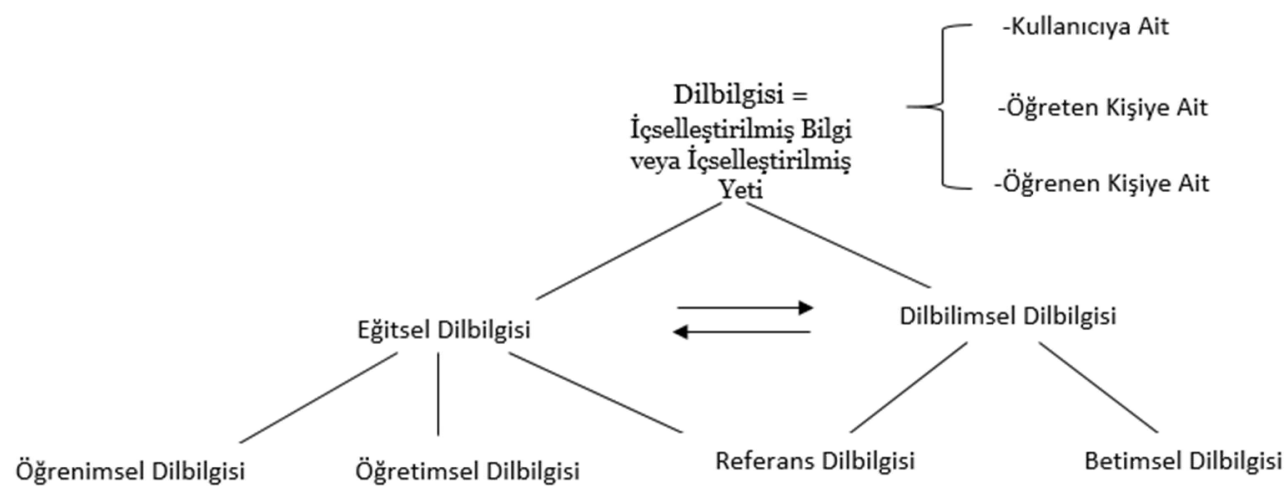

Şekil 1: Germain ve Séguin'e göre dilbilgisi türleri (Dirven'den uyarlanmış, Germain ve Séguin, 1998, s. 48)

Yazarlara göre genel anlamda dil öğretiminde dilbilgisi öğrenimi/öğretiminin; hem öğrenen kişinin söz konusu dil hakkında sahip olduğu ve içselleştirdiği bilgiyle, hem de bu bilgiyi betimleyebilmesiyle/simülasyonunu yapabilmesiyle mümkün olmaktadır (Germain ve Séguin, 1998, s. 46). Yukarıda Germain ve Séguin'in "Dirven'den alınmış, [...] biraz değiştirilmiş ve tamamlanmış [...]" olarak tanımladıkları şemaya göre, dilbilgisi kurallar bütünü olarak değil; öğrenen kişinin özümsemiş olduğu bir yeti olarak ele alınmaktadır. Ayrıca yazarlar sadece genel kullanımdaki kuralların değil belirli bir durumda öğrenen kişinin yararlanabileceği kuralların da hesaba katılmasını savunmaktadırlar (s. 47-48).

Şekil 1'e göre Kullanıcıya ait olan dilbilgisi türü (la grammaire de l'usager), aslında kişinin ana dilinde, bir başka deyişle kullandığı ilk dilde sahip olduğu dilbilgisidir. Öğrenen kişilerin herhangi bir yabancı dili öğrenirken kendi ana dillerinden dayanak aldıkları, bu yabancı dili sürekli onunla karşılaştırdıkları düşünülürse bu "Kullanıcı Dilbilgisi Türü"nün önemi açığa çıkar. Örnek vermek gerekirse ana dilinde fiil veya zarf gibi dilbilgisel sinıflamaları bilmeyen birine yabancı dildeki karşlıklarını öğretmek oldukça zor olacaktır. Öğreten kişiye ait olan dilbilgisi türü (la grammaire de l'enseignant) ise öğretenin bilgiye sahip olma derecesiyle ilgilidir ve burada iki ihtimal söz konusudur: Ya öğreten kişi kendi ana dilini yabancı dil olarak başkalarına öğretiyordur-ki bu durumda öğrettiği dilbilgisi türü aslında küçükken edinmiş olduğu kullanıcı dilbilgisi türüyle karışır-, ya da öğreten kişi öğrettiği dili kendisi de sonradan yabancı dil olarak öğrenmiştir; bu ikinci durumda da kendisi nasıl öğrendiyse tecrübelerine başvurarak öğrenmiş olduğu dilbilgisi yönlerinin öğrenilmesi konusunda öğrenen kişiye başarılı bir rehber olur. Ancak bu ikinci durumda bilgi öğreten kişiyle sınırlı olacağından durum tam tersine de şekillenebilir. Öğrenen kişiye ait dilbilgisi türü (la grammaire de l'apprenant) durağan olmayıp sürekli gelişim halinde olan veya olması gereken dilbilgisine işaret eder (Germain ve Séguin, 1998, s. 48-50). Eğitsel dilbilgisinin alt dallarından biri olan Öğretimsel dilbilgisi türünde (la grammaire d'enseignement) ise daha çok dilbilgisi konularının seçiminin ve öğretimdeki ilerlemenin üzerinde durulmaktadır. Bu dilbilgisi türü söz konusu yabancı dil öğretim kurumunun amaç ve ilkelerini, vizyonunu ve programını doğrudan ilgilendirmektedir; bundan dolayı öğreten kişiye ait dilbilgisi türüyle karıştırılmamalıdır (a.g.e., s. 53, 109-110). Öğretimsel dilbilgisi türünde dikkat çekilen dilbilgisel ilerleme konusuna gelince, sadece dilbilgisini ön planda tutan dil programlarının öğrenen nezdinde yalnızca dilbilgisel terimlerini geliştirdiği ve bunun yerine; daha

\footnotetext{
\begin{tabular}{r|l} 
Adres & Address \\
RumeliDE Dil ve Edebiyat Araşttrmalar Dergisi & RumeliDE Journal of Language and Literature Studies
\end{tabular} Osmanağa Mahallesi, Mürver Çiçeği Sokak, No:14/8 Osmanağa Mahallesi, Mürver Çiçeği Sokak, No:14/8 Kadıköy - İSTANBUL / TÜRKIYE 34714 Kadıköy - ISTANBUL / TURKEY 34714 e-posta: editor@rumelide.com e-mail: editor@rumelide.com, tel: +90 505 7958124, +90 2167730616 phone: +90 505 7958124, +90 2167730616
} 
önce de 3. bölümde söz konusu olan "iletişimsel görev"lere başvurulup dilbilgisi konularının bu görevlerle harmanlanıp öğrenciye verilmesi durumunda ilerlemenin sarmal bir biçimde (spiral ou cyclique) devam edeceği belirtilmektedir. Bahsi geçen sarmal ilerleme şeklinde öncelikle öğrencinin karşısına tüm dilbilgisi konuları eksiksiz olarak çımamakta; önce en basit haliyle görünmekte, ardından aynı öğenin birkaç özelliği daha belirmekte ve daha ileri dil düzeyinde de öğrenci aynı ögenin eksik kalan yanlarıyla karşılaşmaktadır. Bu şekilde en soyut ve karmaşık dilbilgisi özelliği ileri dil düzeylerinde verilmekte; dilbilgisel yapıların öğretimi iletişimsel görevler içinde ve dilsel işlevlere (des fonctions langagières) başvurarak kademeli olarak gerçekleştirilmektedir (a.g.e., s. 109-123). Bir sonraki bölümde Fransızca öğretim kitapları üzerinde yapılacak olan çözümlemede bu konu da dikkate alınacaktır. Eğitsel dilbilgisinin ikinci alt dalı olan Öğrenimsel dilbilgisi türü (la grammaire de l'apprentissage) "öğrenen kişinin doğrudan kullanmasına yönelik somut bir ürün olarak" tanımlanmaktadır. Genellikle dilbilgisinin öğrenimi üzerine hazırlanan kitaplarda karşımıza çıkmaktadır (1998, s. 53).

Eğitsel dilbilgisinin üçüncü ve son alt dalı olan Referans dilbilgisi türü (grammaire de référence) ise şekil 1'de görülebileceği üzere hem eğitsel hem de dilbilimsel dilbilgisi türü başlıklarına dahil edilebilir. Başka bir deyişle ikisinin ortak noktası referans dilbilgisidir. Referans dilbilgisi türü denilince akla bir dili -kuralcı veya betimleyici yola başvurarak- sunma işlemini gerçekleştiren eserler gelmektedir (örn.: Grevisse ve Goosse, 2008, Le Bon Usage, Grammaire Française). Eğitsel dilbilgisini dilbilimsel dilbilgisinden ayırmanın yolu benimsenen amaçtan geçmektedir: Eğitsel dilbilgisi genelde seçicidir, öğrenimi kolaylaştırmak için önceden belirlenmiş konular seçilmekte ve bu şekilde yabancı dilde öğrenen kişinin sahip olması gereken dilbilgisel yeti kullanımı kendisine sunulmaktadır. Ancak dilbilimsel dilbilgisi türünde bir uygulama/kullanma amacı olmadan ve seçici olmadan, olabildiğince geniş konular hakkında sadece dile ait bilimsel açıklamalar yapılmaktadır (Germain ve Séguin, 1998, s. 54-55, 85-107). Dilbilimsel dilbilgisi türünün diğer bir alt dalı da betimsel dilbilgisi türüdür (la grammaire descriptive/simulation grammaticale). Eğitsel dilbilgisi bir dil öğretim kitabına veya bir dil programına dahil edilmişse betimsel veya kuralcı dilbilgisi öğretim yaklaşımlarından biri kullanılmıştır. Bununla birlikte, diğer türlerin aksine, betimsel dilbilgisi ilgili yazarlar tarafından ayrıntılı olarak açıklanmamıştır (a.g.e., s. 10). Tüm bu dilbilgisi tipolojisini açıklayan Germain ve Séguin son olarak şekil 1'deki eğitsel dilbilgisi ve dilbilimsel dilbilgisi türleri arasında bulunan çift yönlü okların, iki türün sürekli etkileşim içinde olduklarını vurgulamak için kendileri tarafından eklendiğini vurgulamaktadırlar. Örneğin bir Fransızca öğretim kitabındaki öğrenimsel dilbilgisi türü, referans dilbilgisi veya dilbilimsel dilbilgisi üzerine inşa edilir (a.g.e., s. 55$56)$.

Mevcut çalışmada dilbilgisi tanımı ve türleri üzerine sözü edilen çalışmaların ardından, belli başlı dil bilimleri alanlarına ve dilbilgisi kuramlarına da dikkat çekmek gerekmektedir. Dilbilgisiyle ilgili çoğu çalışmada karşılaşılan "Tümce Dilbilgisi" ve "Metin Dilbilgisi" burada örnek olarak verilebilir: Birincisinde iletişim durumu verilmez:

[...] bağlamdan bağımsız ve bağlantısız olarak tek tek tümceleri temel alan 'tümce dilbilgisi' belirli kuralları örneklemekte ve öğretmekte işe yarasa da, yaşayan dil ile ilgili sağlam bir fikir vermekten uzaktır. Bu nedenle tümce temelli dilbilgisi, soyut ve yapay kalmaya mahkum olur (Korkut, 2015, s. 160).

Metin dilbilgisi (la grammaire de texte) veya metin dilbilimi (la linguistique textuelle) ise, tümcelerin dizilişiyle ilgilenmektedir, hem tümceüstü hem de tümcelerarası alanlarla ilişkilidir. Metin dilbilgisi metnin yapılandırılmasını sorgular; izlek (le thème) ve yeni bilgilerin (les rhèmes) birbiriyle nasıl

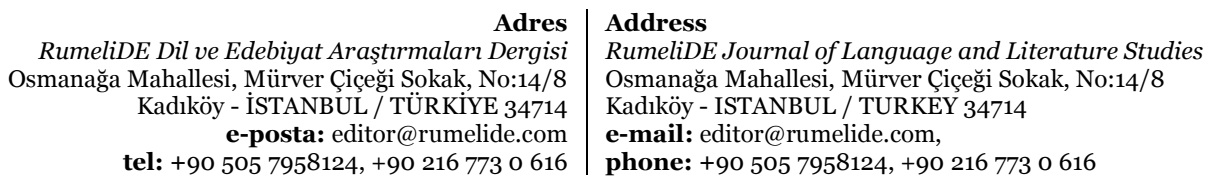


etkileşimli olduğunu ve bu sürecin metindeki ilerlemeyi nasıl etkilediğini belirlemeye çalışır (Korkut, 2015; Onursal, 2003). "Derin yapıda oluşan anlamlar arasındaki mantıksal bağlantı (...) olan ve (...) belli bir yorum süreci gerektir(en) tutarlhlk ( $f r$. la cohérence)" ve ayrıca " Metnin uyumluluğunu sağlayan dilsel öğeler, hem bölümlerin kendi içlerinde, hem de bölümler arasında dilbilgisel, sözdizimsel, anlamsal ve mantıksal bağlantılar kurulmasına yardımcı ol(an) bağdaşıklık (fr. la cohésion)" da metin dilbilgisinin konuları arasındadır (Onursal, 2003, s. 8-14).

\section{Diller İçin Avrupa Ortak Başvuru Metni (OBM) ve B1 düzeyi}

Diller İçin Avrupa Ortak Başvuru Metni’ne göre dil düzeylerini 3 ana başlık altında göstermek mümkündür (MEB, 2009, s. 21):

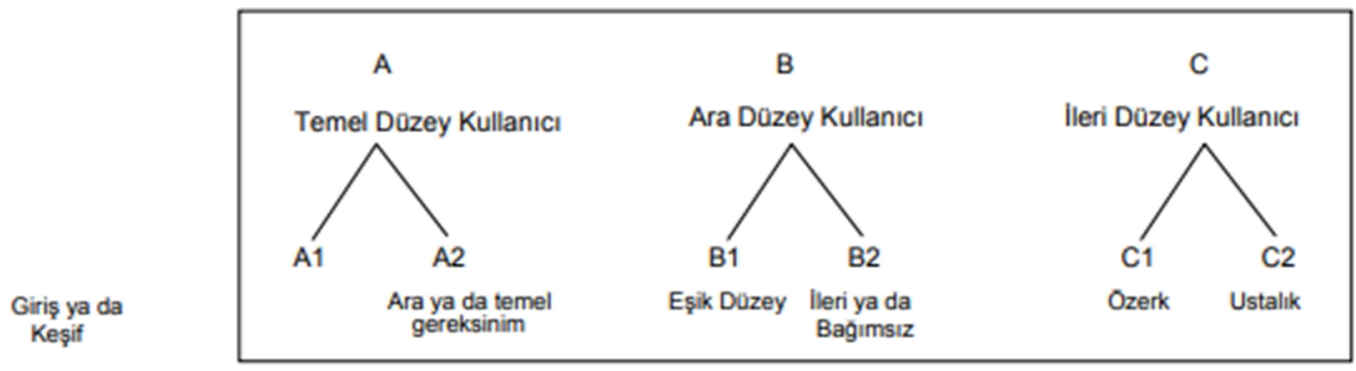

Şekil 2: OBM’ye göre dil düzeyleri

Mevcut çalışmada Défi 3 B1 (2019) ve L'atelier B1 (2020) Fransızca Öğretim Kitapları dilbilgisi öğretimi açısından incelenecektir. Çalışmanın kapsamı göz önünde bulundurulduğunda, tüm dil düzeylerini incelemek mümkün olamayacağından kitap seçimi yapılmadan önce üzerinde durulacak dil düzeyi belirlenmiştir. Dil düzeyinin B1 olarak seçilmesinin nedeni ise yabancı dil öğrenen bir kişinin bu dildeki eşik kabul edilen noktaya bu düzeyde gelmesidir (Niveau Seuil). Söz konusu düzeyde olan bireyler ölçünlü dilde günlük yaşamda ( $\mathrm{ev}$, iş veya okul) duyduklarını kavrayabilmekte ve kendileri de basit söylemler oluşturabilmektedirler. Ayrıca, belli başlı durumları anlatabilmekte, betimleyebilmekte veya neden-sonuç ilişkisini açılayabilmekte, kısacası kendi başlarının çaresine bakabilmektedirler (Conseil de l'Europe, 2001, s. 24). Yabancı dil öğreniminde bu düzeyin yadsınamaz önemi göz önünde bulundurulduğunda, mevcut çalışma için tercih edilmesinin yerinde olacağı düşünülmüştür.

OBM'ye göre, iletişimsel dil yetileri 3 gruba ayrılır: Dilsel yetiler, sosyodilsel yetiler ve edimsel yetiler. Mevcut çalışmayı ilgilendiren dilbilgisel yeti, dilsel yetiler başlığı altında, sözcük yetisi, anlamsal yeti, sesbilgisi yetisi ve yazım kuralları yetisi ile birlikte bulunmaktadır. Söz konusu dilbilgisel yetinin, kuralları ezberleyip yeri geldiğinde papağan gibi tekrarlamak değil; aslında bu kuralları öncelikle anlayabilmek ve sonrasında yeniden farklı ortamlarda kendini ifade ederken kullanabilmek olduğu da belirtilmiştir (MEB, 2009, s. 107).

OBM’ye göre B1 dil düzeyine gelen öğrenenlerin ana dillerinin etkisi net bir şekilde hissedilir ve bundan dolayı bazı dilbilgisi hataları yaparlar; ancak yine de dilbilgisi kontrolleri yüksektir ve ihtiyaçlarını, isteklerini veya düşüncelerini karşı tarafa aktarmayı başarırlar. Ayrıca iletişime geçtiklerinde yabancı dilde en sık kullanılan yapılardan da yararlanmaktadırlar. Bu düzeydeki öğrenenleri iki temel özellik diğerlerinden ayırır: "Birincisi, bu düzeye gelmiş öğrenenin bir etkileşimi

\footnotetext{
\begin{tabular}{r|l} 
Adres & Address \\
RumeliDE Dil ve Edebiyat Araşttrmalar Dergisi & RumeliDE Journal of Language and Literature Studies
\end{tabular} Osmanağa Mahallesi, Mürver Çiçeği Sokak, No:14/8 Osmanağa Mahallesi, Mürver Çiçeği Sokak, No:14/8 Kadıköy - İSTANBUL / TÜRKIYE 34714 Kadıköy - ISTANBUL / TURKEY 34714 e-posta: editor@rumelide.com e-mail: editor@rumelide.com, tel: +90 505 7958124, +90 2167730616 phone: +90 505 7958124, +90 2167730616
} 
sürdürebilme yetisi ve farklı durumlarda isteneni elde etmesidir" (Conseil de l'Europe, 2001, s. 32). Bu etkileşim, "arkadaşlar arasında gerçekleştirilen resmi olmayan bir iletişim [...]" olabilmekte ve öğrenen birey rahatlıkla karşı tarafa fikirlerini aktarabilmektedir. İkincisi ise, bu düzeye gelmiş öğrenen kişinin "günlük yaşamda yaşayabileceği sorunlara ustaca göğüs gerebilmesidir" (s. 32): Bu durumda öğrenen günlük hayatta öngörülemeyen/ beklenmedik herhangi bir olayla başa çıkabilir, bir sohbet sırasında sorulan sorulara yanıt verebilir, herhangi bir görüşme veya sunum sırasında anlamadığı noktalarda açlklama talep edebilir (Conseil de l’Europe, 2001, s. 32-33, 87-90).

\section{Bulgular}

Tablo 1: İncelenen Fransızca öğretim kitaplarılla ilgili genel bilgiler

\begin{tabular}{lllll}
\hline $\begin{array}{l}\text { Fransızca } \\
\text { ögretim kitabı }\end{array}$ & Yayın yılı & Yayınevi & Ünite sayısı & Sayfa sayısı \\
\hline Défi 3 B1 & 2019 & Maison des langues & 9 (Her ünite 14 sayfa) & 277 \\
L'atelier B1 & 2020 & Les Éditions Didier & 10 (Her ünite 16 sayfa) & 215 \\
\hline
\end{tabular}

Maison des langues yayınevinin Fransızca Öğretim kitaplarının Türkiye’deki kullanımının fazla yaygın olmadığı düşünüldüğü için bu çalışmada söz konusu yayınevinde basılmış kitaplardan biri olan Défi 3 $B 1$ (2019) tercih edilmiştir. Tablo 1'den anlaşılacağı üzere, Défi 3 B1'in 9 ünite içerdiği görülmektedir. Her bir ünitenin izleksel olarak 2 dosyaya ayrıldığı, her dosyada ise bir keşif sayfası ve dilbilgisi etkinliklerinin bulunduğu, aynı zamanda öğrenmeyi tetikleyen iki sayfa olduğu saptanmıştır. Défíde önsöz açıkça 2. sayfada "Öğrenende İstek ve Merak Nasıl Uyandırılır?" başlığıyla verilmiştir. Burada kitabın gençlere (les grands adolescents) ve yetişkinlere (les adultes) yönelik geliştirildiği belirtilmiş ve öğrenen kişinin dile ilgi duymasının önemine dikkat çekilmiştir. Kültürel ve sosyokültürel gerçeklerin, dilsel kazanımların gerçekleştirilmesine yardımcı olacağı düşünülmüş; kültürlerarasılık kavramının altı çizilmiştir. Kitapta öğrenen kişiye çeşitli okuma ve dinleme stratejileri sunulacak ve "bu stratejiler ona dokümanları anlama, özerk olarak çalışma ve özellikle becerilerini, bilgilerini geliştirme konusunda yardımcı olacaktır". Bu kitapta dilbilgisi kademeli olarak ve tümevarım yöntemiyle ele alınmıştır; öğrenen kişi ünitelerdeki dilbilgisi konuları üzerine düşünür ve dilbilgisel yetisini kendi kendine oluşturur (Biras, Chevrier, Witta, Fouillet ve Ollivier, 2019, s. 2). Örneğin, 1.ünitede verilen dilbilgisi konularından Bitmemiş Geçmiş Zaman (L’imparfait) ve Yakın Di’li Geçmiş Zaman² (Le Passé Composé) önce metin içinde kullanılmıştır. Ardından da aşağıdaki 10. alıştırmada görülebileceği gibi öğrenen bu iki zaman arasındaki farkın nedenini sorgulamaya teşvik edilmiştir: "Aşağıdaki cümleleri okuyunuz. Neden iki farklı zaman vardır? Ne ifade etmektedirler? " (2019, s. 18-19). Bu şekilde dilbilgisi öncelikle örtük bir şekilde ve tümevarım yöntemiyle verilmiş, daha sonra 11. alıştırmada her iki zamanın da hangi durumlarda kullanıldığı açıklanmıştır.

\footnotetext{
2 Terimlerin Türkçeleri Zeynel Kıran’ın Fransızca Dilbilgisi ve Çeviri Kılavuzu kitabından alınmıștır (2010, s. 222-223). Adres $\mid$ Address 


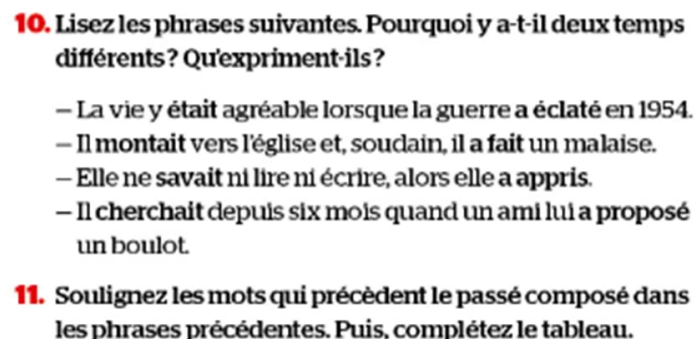

\section{es phrases précédentes. Puis, complétez le tableau.}

\section{L'IMPARFAIT ET LE PASSÉ COMPOSÉ}

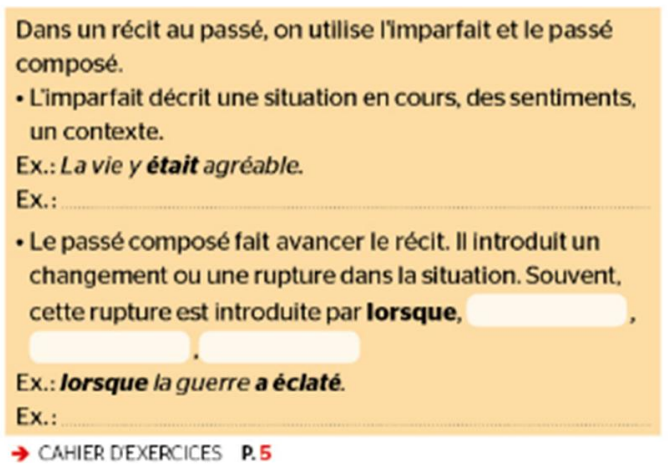

Şekil 3: Défi 3’te dilbilgisi

L'atelier B1 (2020) ise Fransızca Öğretim kitapları Türkiye'de yaygın olarak kullanılan Didier'nin yayımladığı bir kitaptır (Saison, Édito, vb. gibi). Ancak kitap yeni yayımlanmış olduğundan ülkemizde kullanımının henüz yaygınlaşmadığı düşünülmektedir. Kitabın başında önsöz olarak adlandırılan bir sayfa bulunmamakla birlikte içerik açısından ona benzeyen İmalat Strları (Secrets de fabrication) başlıklı bir sayfa görülmektedir (Cocton, Kohlmann, Rabin \& Ripaud, 2020, s. 3). Beklenenin aksine hedef kitle burada belirtilmemiştir, ancak yayınevinin web sitesinde bu kitabın da gençlere ve yetişkinlere yönelik olduğu görülmektedir. Diller İçin Avrupa Ortak Başvuru Metni”ne (OBM) ek olarak Şubat 2018'de yayımlanan ciltte de belirtildiği gibi (le volume complémentaire), bu sayfada da harekete geçme (agir), işbirliği (coopération) ve arabuluculuk (médiation) terimleri vurgulanmıştır. Öğrenen grup burada "imalat atölyesi"ne (atelier de fabrication) benzetilerek grup çalışmasının önemine dikkat çekilmiştir. Tam da imalat atölyelerinde olduğu gibi burada da roller değişebilmektedir. Dolayısıyla öğrenen kişinin bireysel olarak harekete geçmesi, grup içinde de fikirlerini dile getirmeyi öğrenmesi ve aynı iletişimsel yaklaşımda olduğu gibi "kendi öğrenme sürecinin sorumluluğunu" üstlenmesi gerekmektedir (Cocton ve diğ, 2020, s. 3). Yine aynı sayfada iş birliği yapmak (coopérer) başlığı altında dilbilgisi de vurgulanmaktadır: "imalat atölyesinde olduğu gibi araçların önemli bir yeri bulunmaktadır"; bu araçlar da sözcükler, dilbilgisi, fiiller ve seslerin oluşturulması olarak gösterilmektedir (s. 3). Örneğin ünite içerisindeki dilbilgisi kısımları için hep turuncu renk kullanıldığından bu bölümlerin öğrenen tarafından saptanması görsel olarak kolaylaştırılmıştır. İçindekiler (tableau des contenus) bölümünde 10 ünitenin bulunduğu belirtilmiş ve her bir ünite için "Harekete Geçme" başlı̆̆ı altında "Amaçlar"; "İşbirliği Yapmak" başlığı altında "Fikirler", "Misyon" ve "Arabuluculuk"la ilgili terimler gösterilmiş; "Öğrenmek" başlığı altında ise alıştırma kitabındaki üniteyle ilgili alıştırmanın sayfa numarası verilmiştir. Ayrıca her ünite için dilbilgisi, sözcük bilgisi (lexique), ses bilgisi (phonétique) ve kültür/Çağdaş Fransız Edebiyatı sütunlarında ilgili bilgiler verilmektedir (s. 6-11). Défi 3 B1'de olduğu gibi burada da dilbilgisi öğretimi tümevarımlı ve örtük bir şekilde verilmekte, aşağıda da görüldüğü gibi, öğrenen düşünmeye ve kuralı oluşturmaya yöneltilmektedir (Cocton ve diğ, 2020, s. 138):

\footnotetext{
RumeliDE Dil ve Edebiyat Araştırmalar Dergisi Osmanağa Mahallesi, Mürver Çiçeği Sokak, No:14/8 Kadıköy - İSTANBUL / TÜRKIYE 34714 e-posta: editor@rumelide.com tel: +90 $5057958124,+902167730616$ 


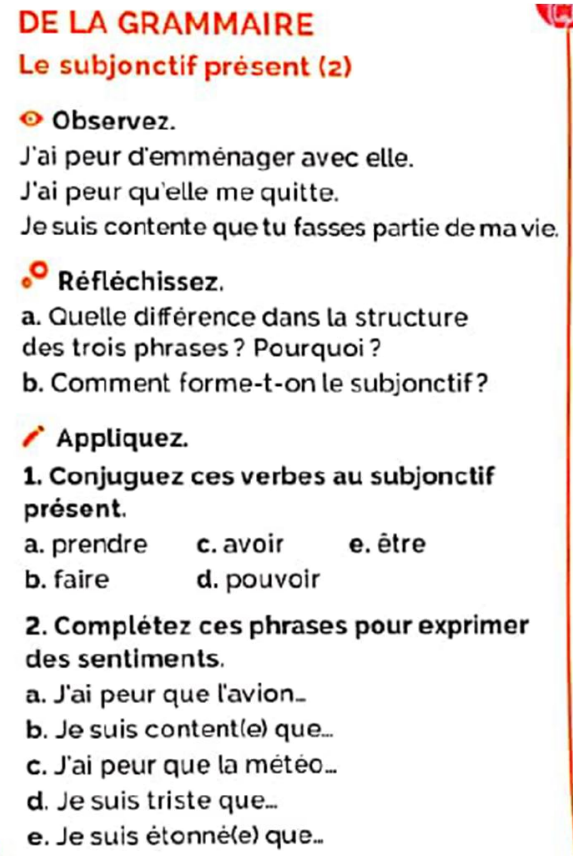

Şekil 4: L'atelier B1'de dilbilgisi

Fransa Milli Eğitim Bakanlığı’na bağlı Uluslararası Pedagojik Eğitim Merkezi’ndeki (bkz. CIEP, Centre International d'Études Pédagogiques) sorumlu kişilerden biri tarafından düzenlenen eğitimde Fransızcanın yabancı dil olarak öğretiminde B1 düzeyinde kazanılması gereken dilbilgisel yetiler aşağıdaki tablonun en soldaki sütununda gösterilmektedir (Izydorczyk, 2015). Ayrıca ortadaki ve sağdaki sütunlarda da incelenen kitaplarda bu konulara yer verilmişse $\checkmark$ ile, yer verilmemişse $X$ ile gösterilmiştir. Soldaki konulardan birinin kitapta bulunup diğerinin bulunmaması durumunda veya belirtilen konuların kitapta herhangi bir cümle içinde geçmesi ancak dilbilgisi konusu olarak ünite içinde açıklanmaması durumunda tabloda Kısmen ibaresi kullanılmıştır.

Tablo 2: İncelenen Fransızca Öğretim Kitaplarındaki Dilbilgisi Konuları

\begin{tabular}{|c|c|c|c|}
\hline \multicolumn{2}{|l|}{ B1 düzeyi için gerekli dilbilgisi konuları } & Défi 3 B1 & L'atelier B1 \\
\hline \multicolumn{2}{|l|}{ Geçmiş Zamanlar (L’imparfait et le passé composé) } & $\checkmark$ & $\checkmark$ \\
\hline \multicolumn{2}{|c|}{$\begin{array}{l}\text { Geçmiş zamanda yardımcı fiillerle ve nesnelerle ilgili uyum konusu } \\
\text { (olmak/sahip olmak/COD) }\end{array}$} & Kismen & $\checkmark$ \\
\hline \multicolumn{2}{|c|}{ Plus-que-parfait, le conditionnel passé et le subjonctif (Olasılık / Zorunluluk) } & Kismen & Kismen \\
\hline \multicolumn{2}{|l|}{ Fikir veya Duygu Bildiren Bazı Fiiller+ Subjonctif } & $\checkmark$ & $\checkmark$ \\
\hline \multicolumn{2}{|l|}{-mesi için kalıbı (Pour que et le subjonctif) } & $\checkmark$ & $\mathrm{X}$ \\
\hline \multicolumn{2}{|l|}{ Zamanların Uyumu (la concordance des temps) } & $\checkmark$ & $\checkmark$ \\
\hline \multicolumn{2}{|c|}{$\begin{array}{l}\text { Geniş ve Geçmiş Zamanlarda Dolaylı Anlatım (Aktarılan Söylem) (Le discours } \\
\text { rapporté) }\end{array}$} & $\checkmark$ & $\checkmark$ \\
\hline \multicolumn{2}{|c|}{$\begin{array}{l}\text { Etken ve edilgen cümle yapıları, özneyi cümle içinde vurgulama ve "On" } \\
\text { öznesinin kullanımı }\end{array}$} & Kismen & Kismen \\
\hline \multicolumn{2}{|l|}{ Bağ-fiil kullanımı (Le gérondif) } & $\checkmark$ & $\checkmark$ \\
\hline \multicolumn{2}{|c|}{ Belirsiz zamir ve sıfatlar (Les adjectifs et pronoms indéfinis) } & $\checkmark$ & $\checkmark$ \\
\hline $\begin{array}{r}\text { Adres } \\
\text { RumeliDE Dil ve Edebiyat Arasstrmalarar Dergisi } \\
\text { Osmanağa Mahallesi, Mürver Ciçeğ Sokak, No:14/8 } \\
\text { Kadıköy - İTANBUL / TÜRKiYE } 34714 \\
\text { e-posta: editor@rumelide.com } \\
\text { tel: +90 505 7958124, +90 } 216773 \text { o } 616\end{array}$ & $\begin{array}{l}\text { Address } \\
\text { RumeliDE Journal of Langua } \\
\text { Osmanağa Mahallesi, Mürver } \\
\text { Kadıöy - ISTANBUL / TURK } \\
\text { e-mail: editor@rumelide.con } \\
\text { phone: +90 505 7958124, +9 }\end{array}$ & $\begin{array}{l}\text { and Literatur } \\
\text { ceği Sokak, Nc } \\
34714 \\
216773 \text { o } 616\end{array}$ & \\
\hline
\end{tabular}




\begin{tabular}{|l|l|l|}
\hline İki zamirin bir arada kullanımı (Les doubles pronoms) & X & $\checkmark$ \\
\hline İlgi adıllı yan tümceler (Les pronoms relatifs simples et quelques composés) & $\checkmark$ & $\checkmark$ \\
\hline Basit Kişisiz Yapılar (Les tournures impersonnelles simples) & $\checkmark$ & $\checkmark$ \\
\hline Zaman ve yer bildiren edatların ve zarfların kullanımı (pendant, depuis, etc.) & $\checkmark$ & $\checkmark$ \\
\hline Neden-sonuç bildiren yapılar & $\checkmark$ & $\checkmark$ \\
\hline $\begin{array}{l}\text { Kronolojik sıralama bildiren bağlaçlar (D’abord, ensuite, enfin, premièrement, } \\
\text { etc.) }\end{array}$ & $\checkmark$ & $\checkmark$ \\
\hline
\end{tabular}

Öncelikle Défi 3 B1 Fransızca öğretim kitabındaki eksikliklere bakılacak olursa, burada geçmiş zamandaki yardımcı fiillerle ve nesnelerle ilgili uyum konusuyla (olmak/sahip olmak/COD) karşılaşlmamıştır. Daha doğrusu asıl verilmesi gereken geçmiş zaman (le passé composé) ve nesnelerin (COD) aynı cümlede bulunması ve uyumun gerekliliği yerine, diğer bir geçmiş zaman (l’imparfait) nesne kullanımıyla birlikte verilmiştir : " Cinq familles la composaient. $\rightarrow$ Cinq familles composaient la caste. La: pronom COD " (s. 41). Geriye kalan örnekler ise geniş zamanda verilmiştir. Ancak diğer açıdan bakılırsa, tüm nesne türlerinin verildiği saptanmıştır (COD,COI, en, y) (s. 41). Etken ve edilgen cümle yapılarına ünitelerde yer verilmiş ancak "on" öznesinin kullanımı dilbilgisi kısımlarında açılanmamıştır. Ayrıca le conditionnel passé kitap içindeki küçük dilbilgisi kısımlarında saptanamamıştır, ancak kitabın en sonundaki dilbilgisi özeti bölümünde bu konu açıklanmıştır ("précis de grammaire", s. 152). İki zamirin bir arada kullanım konusu ve bağ-fiil kullanımları yine ünite içindeki dilbilgisi kısımlarında yer almazken, en sondaki dilbilgisi özeti bölümünde görülmektedir (s. 154-155). Belirtilen konulara kitabın sonunda ayrıntılı olarak yer verilmesi takdir edilebilir, ancak kitabın sonu her an öğrenim sırasında öğrenen tarafından açılmadığından, bu konuların az da olsa ünite içindeki dilbilgisi kısımlarına dahil edilmesi önerilebilir.

Défi 3’te olduğu gibi, L'atelier B1'de de le conditionnel passé konusunda sorunlar bulunmaktadır: Ünitelerin çeşitli sayfalarındaki bölümlerde Le plus-que-parfait, le subjonctif ve le conditionnel présent öğretimi üzerinde durulmuştur (Cocton ve diğ., 2020, s. 76, 118, 119, 127, 163). Ancak konu bazında le conditionnel passé veya le conditionnel présent üzerinde durulmamıştır. Bu konular bazı yerlerde bağlam içinde geçmektedir: "J'aimerais que nous ayons les mêmes droits" (s. 167). Onun dışında kitap sonundaki dilbilgisi bölümünde de bazı fiillerin bu kiplere göre çekimi verilmiştir. L'atelier B1'in dikkatimizi çeken bir başka yönü, On zamirinin kullanımının çeşitli sayfalarda bulunması ama öğretimi için herhangi bir dilbilgisi bölümünde bu zamire yer verilmemesidir (Cocton ve diğ., 2020, s. 72, 83, 117, 140). On kullanımına önceki düzeyde yer verilmiş olabilir, ancak Fransa Milli Eğitim Bakanlığı tarafından kurulan Uluslararası Pedagojik Eğitim Merkezi’ne göre bu konu B1 düzeyinin dilbilgisel yetileri arasında bulunmalıdır (bkz. CIEP, Centre International d'Études Pédagogiques). Benzer bir durum basit kişisiz yapılarda da (Les tournures impersonnelles simples) karşımıza çıkmaktadır. Basit kişisiz yapılar kitabın bazı sayfalarında geçmekte ama konu adı yazmamaktadır (Cocton ve diğ., s. 31, 83, 86). Ayrıca bu konu daha sonra ayrıntılı olarak ve aktarılan söylem başlı̆̆ altında verilmiş, ama yine konu adı belirtilmemiştir (Cocton ve diğ., 2020, s. 95). Burada Nur Kaplan'ın Yüksek Lisans Tez çalışmasından yola çıarak, OBM'de ve eylemsel yaklaşımda "dil üstü dilbilgisel kavramların öğrenen kişi için bir güçlük kaynağı" olarak görüldüğü belirtilebilir. Bu nedenle incelenen her iki öğretim kitabında da, kitabı hazırlayan uzmanlar dilbilgisel kavram kullanımından kaçınmaya çalışmışlardır (Kaplan, 2011, s. 43). L'atelier B1'deki diğer eksiklik ise -mesi için kalıbıdır (Pour que et le subjonctif présent). Söz konusu yapının iki kullanımı olduğundan; 1. ve 2. kullanımında cümle yapıları tamamen farklı olduğundan bu konunun öğretilmesi kaçınılmaz olmalıdır. Ayrıca konu 2. şekilde kullanıldığında, aslında Fransızcada "emin olmadığımız durumlarda

Adres
RumeliDE Dil ve Edebiyat Araştırmaları Dergisi Osmanağa Mahallesi, Mürver Çiçeği Sokak, No:14/8 Kadıköy - İSTANBUL / TÜRKIYE 34714 e-posta: editor@rumelide.com tel: +90 $5057958124,+902167730616$
Address

RumeliDE Journal of Language and Literature Studies

Osmanağa Mahallesi, Mürver Çiçeği Sokak, No:14/8

Kadıöy - ISTANBUL / TURKEY 34714

e-mail: editor@rumelide.com,

phone: +90 5057958124 , +90 2167730616 
bir yargı ve düşünce aracılığıyla bir olayı yorumladığımız zaman" başvurulan subjonctif kipi gerekmektedir (Kıran, 2010, s. 229). Bu durumda bu yapının kitaplarda vurgulanması gerekmektedir. Bu konu Défi 3’te her iki şekliyle karşılaştırmalı olarak verilmiştir (Biras ve diğ., 2019, s. 81). Ancak L'atelier B1'de bu konu yeterince yer almamaktadır.

Her iki kitapta da eksiklik olarak görülebilecek konu, tabloda da belirtildiği üzere, "le conditionnel passé"nin ve "On" öznesinin ayrıntılı olarak açıklanmamasıdır. Belirtilen dilbilgisi konuları ünitelerin içerisindeki dilbilgisi bölümlerinde verilmemiştir.

Cuq Une introduction à la didactique de la grammaire en Français langue étrangère (Fransızcanın Yabancı Dil Olarak Öğretiminde Dilbilgisi Öğretimine Giriş) adlı kitabında "Hangi dilbilgisi seçilmelidir?, Nasıl seçilmelidir? ve Size göre şu anda en iyisi hangisidir?" sorularının sürekli öğretmenler tarafından konuşulduğunun altını çizmektedir. Yazar, genel anlamda Fransızca öğretim kitaplarını ve özellikle değerlendirme boyutunu incelemek için oluşturulan birçok aracın bulunduğunu, ancak dilbilgisi öğretimine özgü herhangi bir araç olmadığını vurgulayıp kendisi bir dilbilgisi çözümleme ölçeği oluşturmuştur. Cuq bu ölçeğin tümüyle öznellikten arındırılmasının olanaksız olduğunu kabul etmekte, ama aynı zamanda kitaplardaki dilbilgisi öğretimiyle ilgili genel bir bakış açısı sunacağını ve esnek bir kullanım alanının olduğunu ileri sürmektedir. Aynı zamanda, herhangi bir öğretim kitabını veya dilbilgisini "seçmek bir ölçüde öznelliği hesaba katmak" değil midir? sorusunu da yöneltmektedir (1996, s. 109-110).

Bu çalışmada, Défi 3 B1 ve L'atelier B1 kitapları Cuq’ün dilbilgisi öğretimi için oluşturduğu ölçeğe göre değerlendirilmiştir. Tüm ölçek mevcut çalışma kapsamında verilemeyeceği için sonuçlar aşağıdaki gibi özetlenmiştir:

- Öncelikle her iki kitabın da öğretmen kitabı, alıştırma kitabı ve alıştırmalar için cevap anahtarının olduğu, bunların yanında her ikisinin de videolar, oyunlar, web site bağlantıları gibi ek materyallere başvurdukları söylenebilir.

- Défi 3 öğretim kitabında bazı ünitelerin başlıklarının içerik açısından net olmadı̆̆ı görülmektedir : "Haydi anlat (Allez, raconte!)" (s. 29). L'atelier B1'de ise Ünite isimleri İş, Aktüalite, Macera, Uzay, Geri dönüşüm gibi net ve tek sözcükle ifade edilmiştir. Ünite içerisindeki metin başlıklarının da net ve metnin içeriğiyle uyumlu olduğu görülmüsstür.

- İki kitap metinlerin netliği açısından karşılaştırılırsa, genel olarak her ikisinde de net ve anlaşılır metinlerin seçildiği saptanmıştır. Défi 3'te seçilen konular, Fransa'daki sarı yelekliler (les gilets jaunes) gibi güncel konulardır (s. 116). L'atelier B1'de ise akıllı telefon, sesli kitap, uzay ve bilimsel gerçekler veya robotlar gibi daha genel konular tercih edilmiştir (s. 21, 83, 114).

- $\quad$ İki öğretim kitabı tablo ve şemalar açısından da karşılaştırılmıştır. Défi 3 B1'de yaratıcı ve akılda kalıcı şemalar, tablolar ve hatta reklam afişleri saptanmıştır (s. 16, 44-45, 63, 70, 75, $78-79,92)$. Her ünitenin bir kapak sayfası bulunmakta ve orada ünitenin temasıly ilgili genel bir başlık, ilgili ünitede bulunan iki ayrı dosyanın tanıtımı ve her dosyada birer son görev (la tâche finale) verilmiştir. Bu kapak sayfasının en altında her dosyada bulunan kültür (ve toplum), iletişim, dilbilgisi ve sözcük bilgisi olarak dört ayrı kısımda konular sunulmuştur (s. 85). Daha sonra bazı açıklamalar verilip boşlukların öğrenen tarafından doldurulması ve yine öğrenenin dilbilgisi kuralını oluşturması beklenmektedir. Örneğin etken/edilgen cümleler verilip bazı noktalarda öğrenen düşünmeye teşvik edilmiştir (s. 89). Bu açıdan, Défi 3 B1'de, L'atelier B1'e göre dilbilgisi konularında öğrenen kişinin daha çok sorgulamaya yöneltildiği, OBM ilkelerinin benimsendiği ve dilbilgisinin daha örtük bir şekilde işlendiği söylenebilir.

L'atelier B1'de ise her ünite başında o ünitenin hangi sayfasında ne olduğu büyük bir şemayla gösterilmiştir. "La Fabrique" olarak adlandırılan sayfada 4 ayrı şema karşımıza çıkar: Sözcük, Dilbilgisi, Fiiller, Ses Bilgisi (Phonétique). Diğer bir güzel yönü ise, konuşma baloncukları içerisinde konuyla ilgili günlük dilden verilen örnek cümlelerdir (Au

Adres $\mid$ Address

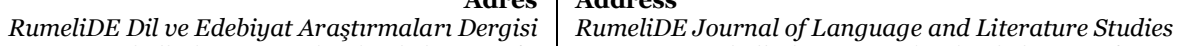

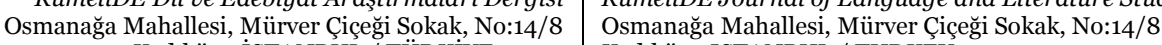

Kadıköy - ISTANBUL / TÜRKIYE 34714 Kadıköy - ISTANBUL / TURKEY 34714 e-posta: editor@rumelide.com

tel: +90 505 7958124, +90 2167730616 phone: +90 505 7958124, +90 2167730616 
quotidien). Bu sayede, öğrenen günlük dilde kullanılan sözcük bilgisi yanında dilbilgisi yapılarına da aşina olabilecek ve Fransa'ya gittiğinde günlük yaşamında arkadaşlarıyla samimi bir dil (familier) kullanabilecektir. Örneğin dilbilgisiyle ilgili kısımda şartlı cümleler ve varsayımlarla ilgili (Si'li cümleler) bilgi verildikten sonra günlük dildeki kullanımları gösterilmiștir ("Si j’étais toi, je me méfierais", s. 119). Her ünitede bulunan Mémo sayfalarında tablo şeklinde gruplandırılan sözcükler, ünitedeki dilbilgisi konu özetleri ve sesbilgisi konuları yer almaktadır (s. 127):

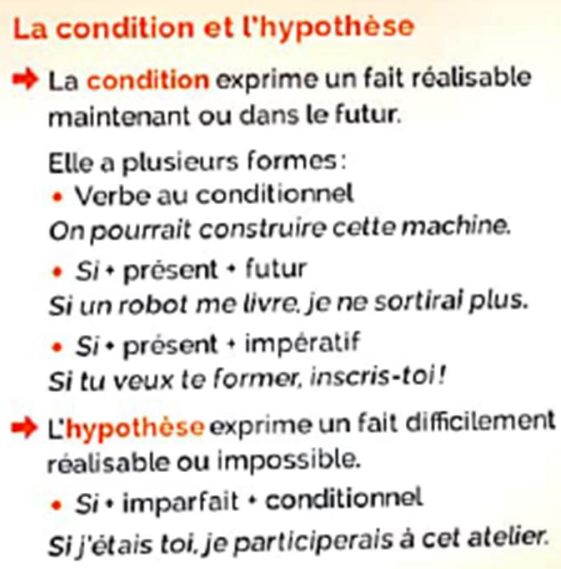

\section{Şekil 5: L’atelier B1'de dilbilgisi konu özetleri}

- Söz konusu kitaplar referans dilbilgisi/öğrenimsel dilbilgisi türleri açısından karşılaştırılırsa, her iki kitabın da yazarlarının öğrenimsel dilbilgisi türüne başvurdukları görülür. Verilen dilbilgisi konuları B1 dil düzeyi için otantik materyaller arasından seçilerek, ünitelerin sözcük bilgisiyle de harmanlanarak belli bir bağlam içerisinde ve kademeli olarak öğrenene sunulmaktadır. Referans dilbilgisi kitapları gibi sırasıyla baştan sona dildeki tüm kurallar verilmemektedir. $\mathrm{Bu}$ öğrenimsel dilbilgisi türü Cuq'ün ölçeğindeki gibi alt başlıklara ayrıldığında her iki kitabın da okul ortamında veya bir öğretmen rehberliğinde gerçekleştirilen eğitim için kullanılabileceği görülmektedir. Ancak ölçekte 3. Alt başlık olan "Öğrenen Kişinin Kendi Kendine Öğrenmesi" şartına sadece Défi 3 B1 kitabının uygun olduğu (ve kitabın önsözünde belirtildiği) saptanmıştır. L'atelier B1'de ise "öğrenenin özerk olmaya davet edildiği" belirtilmişse de, tüm ünitelerde öğrenenlerin gruplar oluşturmalarının ve grup içerisinde rol değișimi yapmalarının gerektiği görülmektedir (la coopération). Dolayısıyla öğrenen bu kitaptaki alıştırmaları başka arkadaşları olmadan, özerk bir şekilde (autonome) yapamayacaktır.

- $\quad$ Ölçeğe göre diğer bir karşılaştırma kullanılan dilin türü (günlük konuşma dili, argo, edebi dil, vb.) ve sözlü/yazılı dilbilgisi açılarından yapılabilir. Bu durum Défi 3 B1'in önsözünde belirtilmemiştir, ancak kullanılan metinlerin otantik oldukları, günlük yaşamdan bağlamla birlikte alınmış olan durumların söz konusu olduğu söylenebilir. Örneğin bir aktörle sorucevap seklinde yapılan görüşmenin aktarılması, gazeteden alınan bir haber, sosyal medyada yazılan iletilerin kullanımı, vb. (s. 68, 78-79, 82). Dilbilgisinin sözlü veya yazılı dilden alındığına dair kitabın önsözünde herhangi bir bilgi verilmemiştir. Bununla birlikte, çoğunlukla yazılı dildeki dilbilgisinin temel alındığı söylenebilir.

L'atelier B1'e gelince, seçilen iletişim durumlarının hem sözlü hem de yazılı dilden seçildiği kitabın önsözünde belirtilmiştir. Kitap boyunca genellikle günlük konuşma dilinin kullanıldığı saptanmış, hatta her ünitede "Au quotidien" başlıklı bir sayfada öğrenenlerin konuyla ilgili Fransa'da günlük hayatta duyabilecekleri cümle yapılarına yer verilmiştir (örn.: s. 23). Bunun yanında her ünitede bir sayfada Çağdaş Fransız Edebiyatından bir yazıdan alıntı yapılmıș ve öğrenen kişinin okuma becerisini geliştirmesi teşvik edilmiştir. Böylece öğrenenin yazı dilinden de uzak kalmaması sağlanmıştır (s. 28).

- Son olarak, kitaplar yöntemsel açıdan karşılaştırılırsa, Défi 3’te genel anlamda herhangi bir dil öğretim yöntem veya yaklaşımından söz edilmediği saptanmıştır. Ancak dilbilgisinin yavaş yavaş, kademeli olarak ve tümevarım yöntemi benimsenerek öğretildiği belirtilmektedir. Ayrıca önsözde kültürlerarasılık kavramının yabancı dil öğretimindeki yadsınamaz yeri; öğrenende ilgi ve merak uyandırmanın önemi vurgulanmaktadır. Söz

\footnotetext{
Adres $\mid$ Address

RumeliDE Dil ve Edebiyat Araştırmalar Dergisi $\quad$ RumeliDE Journal of Language and Literature Studies Osmanağa Mahallesi, Mürver Çiçeği Sokak, No:14/8 Osmanağa Mahallesi, Mürver Çiçeği Sokak, No:14/8

Kadıköy - İSTANBUL / TÜRKIYE 34714 Kadıköy - ISTANBUL / TURKEY 34714 e-posta: editor@rumelide.com e-mail: editor@rumelide.com,

tel: +90 505 7958124, +90 2167730616 phone: +90 505 7958124, +90 2167730616
} 
konusu kavramlar OBM'de de ön plandadır. Buradan yola çıkılarak OBM’de belirtilen eylemsel yaklaşımın bu öğretim kitabında da benimsendiği savına ulaşılabilir.

L'atelier B1'de ise tam olarak bir dil öğretim yönteminden veya yaklaşımından söz edilmese de, önsöz sayılabilecek bölüme göre kitabın, OBM'nin ilkeleri benimsenerek oluşturulduğu söylenebilir (işbirliği ve arabuluculuk). Buradan da kitabın Eylemsel yaklaşımı benimsediği varsayılır. Ayrıca, sarmal şekilde bir öğrenmenin teşvik edildiği de belirtilmektedir (s. 4). Sarmal şeklindeki öğrenme, iletişimsel yaklaşıma dayandığından burada kitabın bu yaklaşımı da benimsediği ve bunun yukarıda sayılan nedenlerden ötürü eylemsel yaklaşımla harmanladığı sonucuna varılabilir.

\section{Sonuç}

Günümüzde yabancı dil eğitim-öğretimi alanında, dilbilgisi öğretimi eskisi gibi bir amaç olmaktan çıkmıştır. Ancak, öğrenen kişi yabancı dilde iletişime geçmek için mutlaka belli bir düzeyde dilbilgisine ihtiyaç duyacağından dilbilgisi öğretimi her zaman önemini korumaktadır. Çalışmamızda hem dilbilgisi türlerini tartışarak hem de yeni basılan kitapları dilbilgisi öğretimi açısından inceleyerek Fransızcanın yabancı dil olarak öğretimi alanına katkı sağlamak amaçlanmıştır. Seçilen güncel Fransızca öğretim kitapları Cuq tarafından geliştirilen ölçeğe göre incelenmiş, bazı eksiklikler saptanmış ve birtakım öneriler getirilmiştir.

Sonuç olarak, Fransızcanın yabancı dil olarak öğretildiği B1 düzeyindeki 2 farklı öğretim kitabında bazı ufak tefek farklılıklar olsa da, dilbilgisi konularının büyük ölçüde paralellik gösterdiği belirtilebilir. Her iki kitapta da dilbilgisi öğretimi örtük olarak ve tümevarım yöntemi benimsenerek planlanmıştır. Ayrıca her iki kitap da Avrupa Ortak Başvuru Metni’ne (OBM) göre belirlenen B1 dilbilgisi konularıyla uyumlu olmakla birlikte birkaç konuda eksiklikleri veya yetersizlikleri hissedilmektedir: Ön plana alınması gereken bazı konulara sadece okuma metinlerinde veya etkinlik sorularında yer verilmesi; ünite içerisinde dilbilgisi için ayrılan kısımlarda bu konuların bulunmaması (-mesi için kalıbı "pour que ve subjonctif", on öznesinin kullanımı) gibi. Belirtilen dilbilgisi yapılarının (subjonctif ve on) başka dillerde birebir karşılıklarının bulunmaması durumunda öğrenenlerin bu konuları anlamaları kolay olmayacaktır. Bu şekilde karmaşık konulara ünite içinde yer verilmemesi, öğrenenin kavramasını zorlaştırmakta ve öğretmene, kitapla öğrenen arasında büyük bir köprü olma görevi yüklemektedir. Bu konuların ünitelere dahil edilmesi öğrenenin özerk olmasına katkı sağlayacak ve Fransızca öğrenimini OBM ilkelerine bir adım daha yaklaştıracaktır.

\section{Kaynakça}

Akbulut, Y. (2012). Veri Çözümleme Teknikleri. A. Şimşek (Ed). Sosyal Bilimlerde Araştırma Yöntemleri içinde (s. 162-195). Eskiş̧ehir: Anadolu Üniversitesi Yayını.

Aydoğu, C., Ercanlar, M. \& Aydınalp, E. B. (2017). Fransızca Yabancı Dil Öğretiminde Eylem-Odaklı Yaklaşıma Dayalı Bir Uygulama Örneği: Nitel Bir Durum Çalışması, Hacettepe Üniversitesi Eğitim Fakültesi Dergisi, 32 (4), 760-779. Çevrimiçi: http://www.efdergi.hacettepe.edu.tr/yonetim/icerik/makaleler/2417-published.pdf, Erişim Tarihi: 11.10.2020.

Balaban Salı, J. (2012). Verilerin Toplanması. A. Şimşek (Ed). Sosyal Bilimlerde Araştırma Yöntemleri içinde (s. 134-161). Eskişehir: Anadolu Üniversitesi.

Bérard, E. (1991). L’approche communicative. Théorie et pratiques. Paris: CLÉ International.

Bérard, E. (2019). Des pratiques grammaticales. Synergies France, 13, 19-29.

Biras, P., Chevrier, A., Witta, S., Fouillet, R. \& Ollivier, C. (2019). Défi 3 B1. Méthode de Français. Livre de l'élève. Paris: Éditions Maison des Langues.

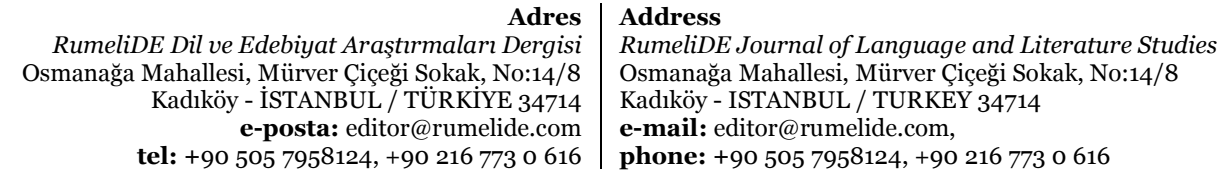

tel: +90 505 7958124, +90 216773 o 616 
Cocton, M.-N., Kohlmann, J., Rabin, M. \& Ripaud, D. (2020). L'atelier B1. Agir, Coopérer, Apprendre. Méthode de Français. Paris: Les Éditions Didier.

Conseil de L'Europe. (2001). Cadre Européen Commun de Référence Pour Les Langues: Apprendre, Enseigner, Évaluer. Strasbourg: Didier. Çevrimiçi: https://rm.coe.int/16802fc3a8, Erişim Tarihi: 06.09.2020.

Cuq, J.-P. (1996). Une introduction à la didactique de la grammaire en Français langue étrangère. Paris: Didier.

Germain, C. (1993). Évolution de l'enseignement des langues : 50oo Ans d'histoire. Paris: CLÉ International.

Germain, C. ve Séguin, H. (1998). Le point sur la grammaire. Paris: CLÉ International.

Grevisse, M. ve Goosse, A. (2008). Le Bon Usage, Grammaire Française. 14 édition. Bruxelles: Éditions De Boeck Université.

Izydorczyk, F. (2015). CIEP DELF B1 Eğitimi Ders Notları (Stage d'habilitation des examinateurscorrecteurs, Niveau B1), 9-11 Ekim 2015, Ankara.

Kaplan, N. (2011). L'étude de la grammaire dans le manuel de FLE "Salut". Yüksek Lisans Tezi. Gazi Üniversitesi, Ankara.

Kıran, Z. (2010). Fransızca Dilbilgisi ve Çeviri Kılavuzu. Ankara: Seçkin.

Korkut, E. (2015). Metin Dilbilimi ve Dil Öğretimi. E. Korkut ve I. Onursal Ayırır (Eds), Dil Bilimleri ve Dil Öğretimi içinde (s. 159-188). Ankara: Seçkin Yayıncılık.

Kuduz, E. (2019). L'utilisation des tâches dans l'enseignement du FLE (Yayınlanmamış Yüksek Lisans tezi). Hacettepe Üniversitesi, Ankara.

Le Robert Dixel Mobile (t.y.). Bir akıllı telefon uygulaması olan Fransızca sözlük.

Mawushi ve Ganyo, (2015). L'Approche communicative et enseignement/apprentissage du FLE dans le contexte plurilingue ghanéen. Regard sur trois manuels d'enseignement : Arc-en-ciel, Latitudes et Panorama, International Journal Of Humanities And Cultural Studies, 2 (1), 371-381.

MEB (2009). Diller İçin Avrupa Ortak Başvuru Metni. Öğrenme-Öğretme-Değerlendirme. Çevrimiçi: http://www.dilbilimi.net/ab_diller_icin_ortak_avrupa_basvuru_metni_meb_tarafindan.pdf, Erişim Tarihi: 06.10.2020.

Neveu, F. (2015). Dictionnaire des sciences du langage. Paris: Armand Colin.

Onursal, İ. (2003). Türkçe metinlerde bağdaşıklık ve tutarlılık. Günümüz Dilbilim Çalışmaları. İstanbul: Multilingual Yayınları, s. 121-132. Çevrimiçi: http://www.egeedebiyat.org/docs/238854.pdf, Erişim Tarihi: 21.10.2020.

Özçelik, N. (2012). L'enseignement et l'apprentissage de la grammaire en classe du fle, Ondokuz Mayıs Üniversitesi Ĕ̆itim Fakültesi Dergisi, 31 (1), 175-186.

Puren, C. (1988). Histoire des méthodologies de l'enseignement des langues. Paris: Nathan-CLE International.

Puren, C. (2016). De l'approche communicative à la perspective actionnelle : exercice de décodage d'une «manipulation génétique ». Çevrimiçi: www.christianpuren.com/mestravaux/PUREN_2016a Erişim Tarihi: 06.10.2020.

Riegel, M., Pellat, J.-C. ve Rioul, R. (2004). Grammaire Méthodique du Français. Paris: Quadrige/PUF.

Sayd, T. (2015). L'approche actionnelle et ses particularités en comparaison avec l'approche communicative, Synergies Turquie, $8,13-28$. Çevrimiçi: https://www.gerflint.fr/Base/Turquie8/saydi.pdf, Erişim Tarihi: 11.10.2020.

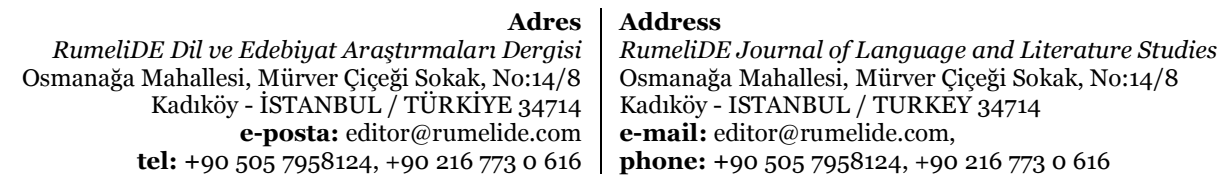

